\title{
ANALISIS KEBUTUHAN KOMPETENSI DAN PENYUSUNAN MODEL AWAL PELATIHAN IN-SERVICE BERBASIS KOMPETENSI DALAM MENINGKATKAN PROFESIONALISME BABY SITTER
}

\author{
Viena Rusmiati Hasanah \\ e-mail: vienarusmiati@yahoo.com \\ Universitas Pendidikan Indonesia
}

\begin{abstract}
Abstrak: Pengasuh anak yang disalurkan melalui lembaga dan telah menyelesaikan pelatihan, ternyata masih belum memiliki pengetahuan mengenai standar kompetensi mereka. Penelitian ini bertujuan menganalisis kebutuhan kompetensi serta kompetensi berbasis model in-service training dalam rangka meningkatkan profesionalisme pengasuh anak. Penelitian ini menggunakan metode penelitian kualitatif dengan observasi, wawancara dan FGD (Forum Group Discuss). Penelitian ini dilakukan di tiga lembaga pelatihan untuk pengasuh anak di Bandung, Jawa Barat dari Januari 2011 hingga Agustus 2011. Hasil penelitian menunjukkan: (1) analisis kebutuhan kompetensi menunjukkan bahwa pengasuh anak saat ini membutuhkan pelatihan yang dapat membantu mereka meningkatkan kemampuan dan pengetahuan serta kompetensi berdasarkan kebutuhan lapangan dan mengacu pada standar yang ditetapkan; (2) model konseptual kompetensi berbasis in-service training terdiri dari pengembangan standar kompetensi mix yang dibangun, penentuan strategi pelatihan manajemen, strategi dan metode pembelajaran dalam pelatihan, dan berbagai perangkat pelatihan yang dibutuhkan. Penelitian ini menyimpulkan bahwa pengasuh anak saat ini butuh meningkatkan kompetensi mereka untuk menjadi profesional di masa depan.
\end{abstract}

Kata kunci: profesionalisme pengasuh anak, kompetensi, in-service training berbasis kompetensi

\section{NEED ASSESSMENT OF COMPETENCY AND COMPETENCY BASED IN SERVICE TRAINING MODEL TO IMPROVING THE PROFESSIONALISM OF BABY SITTER}

\begin{abstract}
Baby sitters, at the present, though they are distributed through workers distribution services and have completed the training, all parties have not yet acknowledged their standards of competency. This research aims at analyzing the needs of competency and investigating competency-based in-service training model in order to improve baby sitters' professionalism. This research utilizes qualitative research method with observation, interview and FGD (Forum Group Discuss) as the technique. The research was conducted at three of training institute for baby sitter in Bandung, West Java from January 2011 until August 2011. The results show that: 1) the analysis of competency's needs shows that baby sitters at present need a training that can help them improve their ability and knowledge as well as competency based on the field's needs and standards referring to standard imposed. 2) The conceptual model of competency-based in-service training comprises the development on mix standard competencies that are built, the determination of training management strategy, the strategy and learning method in the training, and various apparatus of training needed. The research concludes that baby sitters at present need improvement in their competencies in order to be professional in future.
\end{abstract}

Key words: Baby sitters' professionalism, competency, in-service training with competency based

\section{PENDAHULUAN}

\section{Latar Belakang}

Jasa perawatan anak di rumah pada keluargakeluarga di Indonesia, khususnya di daerah perkotaan, banyak yang menggunakan jasa baby sitter. Keluargakeluarga muda ini, umumnya menggunakan jasa baby sitter di rumah mereka masing-masing untuk merawat bayi dan anak-anak mereka karena kedua orangtuanya harus bekerja di luar rumah. Di samping jenis keluargakeluarga yang orang tuanya bekerja, ada pula keluarga yang tetap menggunakan jasa baby sitter di rumah mereka meskipun ibunya tidak bekerja, namun baby sitter berfungsi untuk membantu dalam menjaga dan merawat anak-anak mereka.

Kecenderungan fenomena yang saat ini terjadi 
mengakibatkan kebutuhan akan tenaga kerja untuk perawatan anak yang umumnya dilakukan di rumahrumah adalah cukup besar. Ada daftar tunggu (waiting list) untuk kebutuhan pelayanan baby sitter sedangkan sangat sedikit tenaga yang ingin menjadi baby sitter apalagi yang telah memperoleh berbagai bentuk pendidikan dan pelatihan atau persiapan untuk perawatan anak di rumah.

Saat ini perawatan anak di rumah belum diatur oleh sebuah aturan yang diakui dan dijalankan oleh berbagai pihak terkait karena meskipun pemerintah telah menentukan seperangkat standar kompetensi baby sitter dalam Standar Kompetensi Kerja Nasional Indonesia (SKKNI), namun standar ini tidaklah diakui secara meluas dalam pelaksanaannya. Institusiinstitusi yang menyediakan tenaga baby sitter melalui pelatihan-pelatihan yang dilaksanakan, sangat bervariasi dalam penetapan kurikulum yang berkaitan dengan kompetensi baby sitter. Secara nasional, belum ada kurikulum yang menggambarkan standar kompetensi baby sitter dan pedoman pelatihan dalam penyiapan tenaga kerja baby sitter.

Berdasarkan identifikasi masalah di atas, peneliti merumuskan beberapa pertanyaan penelitian (1) Bagaimana kondisi empirik model pelatihan dan kompetensi baby sitter yang ada saat ini? (2) Bagaimana model konseptual pelatihan in-service berbasis kompetensi yang dapat meningkatkan profesionalisme baby sitter?

Tujuan penelitian ini adalah untuk mengembangkan model pelatihan in-service bagi baby sitter berbasis kompetensi yang sesuai dengan prinsip perkembangan, perawatan dan pendidikan anak usia dini untuk meningkatkan profesionalisme baby sitter. Atas dasar itu, maka tujuan khusus penelitian ini adalah untuk mendeskripsikan kondisi empirik dari model pelatihan yang saat ini dilaksanakan dan kompetensi baby sitter yang ada dan mengkonstruk model konseptual pelatihan in-service berbasis kompetensi yang dapat meningkatkan profesionalisme baby sitter.

\section{METODOLOGI PENELITIAN}

\section{Jenis Penelitian}

Penelitian ini bagian dari penelitian pengembangan (Research and Development). Adapun untuk tahapan ini, penelitian yang dilakukan menggunakan pendekatan kualitatif inquiry melalui wawancara, angket dan forum group discuss (FGD) serta penelusuran data dokumen.

\section{Tempat dan Waktu Penelitian}

Penelitian ini dilakukan di 3 lembaga pelatihan dan penyalur tenaga baby sitter di Kota Bandung. Ketiga lembaga tersebut yaitu Muslimah Center Yayasan Daarut Tauhiid, LPK Bina Mandiri Dago dan LPK Mutiara Bandung. Penelitian ini dilaksanakan mulai dari bulan Januari sampai dengan Agustus 2011

\section{Prosedur Penelitian}

Subjek penelitian meliputi 3 orang pengelola lembaga, 20 orang baby sitter dan juga 5 keluarga pengguna jasa baby sitter.

Langkah-langkah yang dilaksanakan merujuk pada tujuan penelitian ini adalah meliputi :

1. Pengumpulan data kompetensi baby sitter yang sudah bekerja melalui wawancara, angket dan diskusi forum grup mengenai fokus pada kompetensi yang diharapkan.

2. Menganalisis dan membangun kompetensi yang diharapkan dan diperlukan bagi pelatihan in-service bagi baby sitter. Kompetensi ini dibangun dengan melakukan strategi tertentu, yaitu :

a. Mengumpulkan data hasil need assessment mengenai kompetensi baby sitter yang diharapkan oleh keluarga pengguna jasa, tenaga kerja baby sitter pengalaman dalam pekerjaan, dan harapan dari lembaga pelatihan (kebutuhan yang dirasakan).

b. Menggunakan standar kompetensi yang merupakan mix-competence antara SKKNI (Standar Kompetensi Kerja Nasional Indonesia) dan Standar Pendidikan anak usia dini, yang juga menjadikan patokan standar kompetensi yang sudah established di internasional, yaitu menggunakan sertifikat III di Australia, sebagai kebutuhan yang diasumsikan.

c. Mengumpulkan data dan keseluruhan data kompetensi yang diharapkan (assummed need) and yang dirasakan (felt need) dianalisis untuk selanjutnya diambil irisannya sehingga didapatkan hasil data kebutuhan kompetensi yang akan dikembangkan dalam pelatihan in-service.

d. Keseluruhan kompetensi yang dikembangkan dipersiapkan berbagai komponen kurikulumnya. Pengembangan materi pembelajaran untuk kompetensi yang dibutuhkan untuk mendukung baby sitter dalam mencapai kompetensi tersebut dilakukan dengan: Mempersiapkan silabus dan kriteria unjuk kerja kompetensi, Mempersiapkan RPP, Mempersiapkan bahan ajar

3. Menghasilkan desain model awal pelatihan inservice berbasis kompetensi dalam meningkatkan 
profesionalisme baby sitter. Untuk mencapat tujuan ini dilakukan dengan cara :

a. Mempersiapkan desain pelatihan dan menentukan lama waktu pelaksanaan, yang termasuk didalamnya adalah desain pembelajaran yang meliputi: (1) teknik dan strategi serta pendekatan dalam pembelajaran, (2) mempersiapkan media pembelajaran yang sesuai dengan pendekatan yang digunakan, (3) mempersiapkan instrumen dan format evaluasi berupa format tes tertulis, panduan observasi dan wawancara serta format tes unjuk kerja bagi baby sitter.

4. Mempersiapkan delivery system dalam pelatihan in-service dengan melakukan persiapan berbagai komponen dalam model pelatihan. Berbagai komponen yang dipersiapkan meliputi komponen kelembagaan, sosiali-sasi program pada keluarga pengguna jasa, pemateri, tempat, sarana prasarana, waktu, biaya, termasuk strategi dan metode pembelajaran dalam pelatihan serta instrumen evaluasi program.

5. Melakukan validasi model konseptual dalam pelatihan in-service kepada para pakar akademisi dan praktisi.

6. Melakukan revisi atas berbagai masukan dalam model pelatihan in-service dalam meningkatkan kompetensi baby sitter.

\section{HASIL DAN PEMBAHASAN}

\section{Kondisi Empirik Model Pelatihan dan Kompetensi Baby Sitter}

Ketenagaan baby sitter atau pengasuh anak menjadi kebutuhan masyarakat di kota yang saat ini tidak terelakkan lagi. Semakin meningkatnya jumlah ibu bekerja di luar rumah, menjadikan anak yang masih balita haruslah mendapatkan pengasuhan dari seseorang pengganti ibu.

Kondisi empirik yang ada bahwa jasa tenaga pengasuh anak di rumah atau baby sitter dapat dibagi menjadi beberapa kategori, yaitu :

a) Baby sitter/pengasuh anak yang berasal dari pihak keluarga sendiri (nenek, ua, bibi, dil)

b) Baby sitter/pengasuh anak yang berasal dari lembaga penyalur tenaga kerja baby sitter

c) Baby sitter/pengasuh anak yang berasal dari pembantu rumah tangga yang dialihfungsikan sebagai pengasuh anak plus

d) Baby sitter/pengasuh anak yang sengaja diambil oleh keluarga dari tempat asalnya untuk fokus mengurus anak, dengan pola didikan yang langsung didapatkan dari keluarga

Lembaga kursus dan pelatihan yang ada di kota Bandung, beberapa ada yang memfokuskan pada penyiapan dan penyaluran tenaga kerja baby sitter, namun lebih banyak yang bersatu dengan pengadaan tenaga pembantu rumah tangga (PRT), satpam, pengasuh orang tua, dan supir. Berbagai lembaga kursus yang ada, beberapa sudah memiliki ijin dari Dinas Tenaga Kerja berkenaan dengan ketenagakerjaan, namun kenyataannya bahwa bagi lembaga kursus pun diharuskan terdaftar secara resmi di dinas pendidikan setempat, khususnya di kota bandung.

Berbagai karakteristik asal dari tenaga baby sitter/pengasuh anak, memberikan asumsi bahwa umumnya tenaga kerja baby sitter memberikan jasa kepengasuhan sesuai dengan pengalaman yang diterimanya, bukan berdasarkan sebuah proses pembelajaran yang secara khusus diberikan. Artinya dapat dikatakan bahwa tenaga kerja yang berasal dari lembaga seharusnya memiliki tingkat kompetensi lebih tinggi dibandingkan pengasuh anak/baby sitter yang tidak melalui lembaga. Meskipun pertanyaan selanjutnya adalah standar kompetensi seperti apa yang seharusnya dimiliki oleh tenaga pengasuh anak/ baby sitter.

Dalam mengidentifikasi standar kompetensi untuk tenaga baby sitter dilakukan upaya pengkajian terhadap draf Standar Kompetensi Kerja Nasional Indonesia (SKKNI) untuk baby sitter pemula, pencarian berbagai draft standar kompetensi untuk baby sitter yang diakui internasional, melakukan validasi bahasa dari standar kompetensi certificate III yang digunakan di Australia, dan mengkaji standar pendidikan Anak Usia Dini dalam Permendiknas no.58 tahun 2009.

Identifikasi kebutuhan kompetensi baby sitter, dilakukan dengan diadakan forum grup discuss dengan baby sitter dengan fasilitasi dari lembaga penyalur tenaga baby sitter, dilakukan wawancara dengan lembaga penyalur tenaga kerja baby sitter, lembaga penyalur tenaga kerja baby sitter, dan keluarga pengguna jasa.

Berdasarkan data yang didapatkan berdasarkan hasil forum grup dengan sekelompok baby sitter yang berasal dari lembaga, secara umum, baby sitter di lapangan mendapatkan cukup banyak permasalahan, khususnya dalam hal penyesuaian dengan keluarga dan yang paling utama adalah dalam interaksinya dengan anak. Harapan dari baby sitter bahwa mereka menginginkan apabila ada kumpulan selanjutnya, 
dapat diberikan materi-materi untuk meningkatkan pengetahuan serta keterampilan mereka. Beberapa materi tersebut adalah berkenaan dengan cara yang baik dalam mengurus, membimbing dan menghadapi anak, diantaranya :

1) Materi mengenai cara cepat disukai dan memahami anak

2) Materi mengajarkan kebiasaan yang baik pada anak

3) Materi mengenai kreatifitas dan inisiatif baby sitter

4) Materi cara menghadapi kritik dari mitra dan lingkungan

5) Materi mengenai komunikasi dalam memberitahu apabila anak itu salah

6) Materi tentang menu makanan anak sesuai usia

Adapun hasil wawancara dengan keluarga dan informasi yang didapatkan dari penyalur tenaga kerja baby sitter, terkadang ada beberapa kritikan dan saran yang masuk mengenai baby sitter yang mereka salurkan. Meskipun keluarga pengguna jasa pun mengungkapkan tingkat pengharapan pada baby sitter yang tidak terlalu muluk, dengan keberadaan tenaga baby sitter dengan usia muda, tingkat pendidikan SMP dan belum berpengalaman, namun pada prinsipnya standar minimal baby sitter yang ada diharapkan, diantaranya: (1) memiliki kebersihan diri, (2) kerapihan, (3) bisa menyesuaikan diri dengan anak dan keluarga, (4) mampu mengurus kebutuhan anak seperti susu, makan dan pakaian anak dengan baik, dan (5) dapat menjadi penghubung antara orang tua dan anak, khususnya mendengarkan kebutuhan anak ketika orang tuanya tidak ada.

Dari standar minimal yang diharapkan keluarga tersebut, ada pula beberapa komplain yang disampaikan sekaitan dengan performance kerja baby sitter yang didapatkan dari data komplain kepada penyalur tenaga kerja dan juga dari hasil wawancara serta angket. Beberapa masukan tersebut diantaranya adalah: (1) kurangnya kebersihan badan, bau badan dan penampilan tidak rapi; (2) tidak cekatan dalam mengatur waktu, artinya lambat, (3) tidak siap ketika dikritik majikan; (4) ada yang belum mengetahui tentang manajemen penyiapan ASI; (5) beberapa menyerah ketika anak tidak mau makan; (6) ada yang kurang sopan kepada keluarga sehingga kurang keterampilan mengenal dan memahami mitra; (7) kurang dalam membujuk anak dan mengetahui kesenangan anak; 8) kurang kreatif dan inisiatif baby sitter kepada anak; 9) masih perlu diingatkan untuk memasak makanan anak dan mencuci botol hygienis; (10) kurang mengetahui dalam menyusun menu makanan menarik untuk balita; (11) ada yang belum memahami cara merawat pakaian anak; (12) ada yang sikap dan perilakunya juga bahasa yang belum memberi contoh serta mengajarkan kebiasaan baik pada anak; (13) ada yang belum bisa menjaga kebersihan diri dan lingkungan; (4) kurang interaksi dalam mengajak anak bermain yang mendidik. Kenyataan akan kemampuan dan kompetensi baby sitter tersebut didapatkan dari hasil wawancara dengan tiga lembaga penyalur tenaga kerja di kota bandung, forum grup mengenai curhat baby sitter dan ungkapan beberapa keluarga pengguna jasa yang menggunakan jasa baby sitter.

Temuan dari hasil studi pendahuluan mengenai kebutuhan kompetensi di lapangan pada jasa tenaga kerja baby sitter tersebut dapat dipahami karena memang belum tertanganinya dengan baik penyelenggaraan pelatihan yang ada. Pada beberapa lembaga yang peneliti datangi seperti Bina Mandiri Dago dan Yayasan Widia Rejeki Tama Kiara Condong, penilaian akan kompetensi calon tenaga baby sitter yang dilaksanakan lembaga pelatihan, hanya dengan melihat latar belakang tenaga kerja. Bagi calon tenaga kerja yang misalnya mengaku pernah mempunyai anak, maka dia hanya menjalani serangkaian tes yang dilakukan oleh pengelola. Tes yang dilakukan diantaranya dengan melihat simulasi cara menggendong boneka bayi, memandikan, memakaikan baju, dan sebagainya. Bahkan penentuan waktu pelatihan yang akan dilaksanakan lebih kepada "feeling" dari pengelola pelatihan saja. Pelatihan seperti di atas tentunya sangat instan dan hanya berbasiskan pada kebutuhan pengguna jasa semata yang sifatnya sangat mendesak.

Penyusunan Model Pelatihan in-service Berbasis Kompetensi untuk Meningkatkan Profesionalisme Baby Sitter

1. Deskripsi Model Konseptual Pelatihan In-service Berbasis Kompetensi

Desain model konseptual dari pelatihan inservice berbasis kompetensi ini melalui tahapan pengelolaan pelatihan. Konsep pengelolaan pelatihan secara umum meliputi kegiatan perencanaan, pengorganisasian, pelaksanaan, dan evaluasi (Sudjana, 2000:186). Adapun dalam pelatihan berbasis kompetensi, menyaratkan adanya standar kompetensi yang menjadi acuan.

Untuk menyusun rancangan model pelatihan ini, dilakukan berbagai tahapan sebagai berikut yaitu :

a. Melakukan identifikasi dan pengumpulan informasi mengenai standar kompetensi baby sitter yang ideal dan kebutuhan kompetensi yang ada,

b. Melakukan penyusunan tujuan pelatihan yang akan dilaksanakan yang meliputi kompetensi yang akan dituju yaitu pengetahuan, ketrampil- 
an, sikap dan nilai.

c. Menyusun kurikulum pelatihan, yang melingkupi berbagai komponennya seperti tujuan yaitu kompetensi dan kriteria unjuk kerja, silabus dan RPP, materi, media, metode, alokasi waktu, dan evaluasi pembelajaran.

d. Melakukan penyiapan delivery system program pelatihan, dimulai dari sosialisasi kepada lembaga/stake holders yang berkaitan dan akan dilibatkan dalam pelaksanaan uji coba pelatihan in-service bagi baby sitter, pendekatan kepada keluarga yang menggunakan jasa baby sitter atas referensi dari lembaga penyalur, pendekatan kepada baby sitter yang sedang bekerja melalui berbagai cara.

e. Melakukan persiapan delivery system dalam pembelajaran, yang dilakukan dengan melakukan koordinasi dengan tutor mengenai strategi pembelajaran dalam pelatihan sampai pada penyusunan skenario pembelajaran, melakukan pelatihan untuk fasilitator, menyusun panduan bagi tutor dan fasilitator

f. Melakukan persiapan untuk evaluasi dan uji coba keefektifan model, dilakukan dengan menyiapkan berbagai format evaluasi, mulai dari format tes tulisan, format panduan observasi dan panduan wawancara yang sesuai untuk penyelenggaraan pelatihan.

Hal tersebut sejalan dengan apa yang disampaikan mengenai sebuah sistem pelatihan in-service berbasis kompetensi yang komprehensif menurut Rycus (2000) dapat dilakukan melalui beberapa tahapan yaitu :

a. Mendefinisikan target peserta pelatihan, yang dalam penelitian ini mengandung makna menyusun, melakukan validasi dan menetapkan standar kompetensi yang akan menjadi acuan.

b. Melakukan analisis tugas dalam pekerjaan. Tujuan utama dari pelatihan in-service berbasis kompetensi adalah mendukung ketercapaian "praktek terbaik", sehingga penting sekali untuk mendefinisikan dan menggabungkan baik standar unjuk kerja yang merefleksikan "best practice" dan aktivitas-aktivitas pekerjaan yang penting untuk membutuhkan "best practice" tersebut.

c. Membangun kompetensi-kompetensi. Kompetensi adalah seperangkat elemen-elemen yang terdiri dari pengetahuan dan keterampilan yang dibutuhkan dalam mengefektifkan penampilan dari sebuah tugas pekerjaan.

d. Penilaian kebutuhan pelatihan individu (Indi- vidual Training Need Assessment/ITNA)

Pada tataran ini, dibutuhkan pula identifikasi kebutuhan secara individu dari asing-masing peserta pelatihan.

e. Identifikasi dan pemilihan kurikulum. Kurikulum adalah menjadi jantungnya pelatihan sehingga kegiatan ini dapat dilaksanakan dengan baik. Unit kompetensi mendukung perkembangan anak (KOMPA) ditetapkan sebagai unit kompetensi yang akan dikembangkan.

f. Mengembangkan perencanaan pelatihan. Pada tahapan ini, dilakukan berbagai persiapan berkaitan dengan delivery system dalam pelatihan yang akan dirancang.

g. Menyelenggarakan pelatihan. Penyelenggaraan pelatihan merupakan puncak pelaksanaan model ini.

h. Mengimplementasikan aktivitas pembelajaran/ Transfer of Learning. Aktivitas pembelajaran dalam pelatihan berbasis kompetensi ini menggunakan pendekatan mastery learning dan experiential learning.

i. Melakukan evaluasi dan balikan.

Berdasarkan pemikiran diatas, komponen model yang dikembangkan dalam pelatihan in-service ini meliputi rasional model, tujuan, pengembangan standar kompetensi, sasaran, prinsip penerapan, dan deskripsi sebagai berikut :

1) Rasional Model

Model ini mencoba mengembangkan dua hal utama, yaitu pertama, mengembangkan standar kompetensi bagi baby sitter yang secara ideal dapat dijadikan patokan dalam pelatihan dan kedua, mengembangkan model pelatihan in-service yang tepat bagi tenaga kerja baby sitter yang sudah bekerja di keluarga-keluarga pengguna jasa.

Model pelatihan ini dapat menggunakan pendekatan mastery learning. Dalam pendekatan ini, beberapa variabel yang digunakan oleh pendidik yaitu : (1) variabel petunjuk, (2) penguatan, (3) partisipasi siswa, (4) umpan balik dan (5) koreksi. Variabel-variabel tersebut digambarkan oleh Bloom sebagai kegiatan mengajar yang berkualitas. Menurut teori ini, jika fitur pengenalan terhadap siswa (aspek kognitif dan afektif siswa) yang terkait dengan kegiatan mengajar adalah positif dilakukan, maka hasil belajar akan mencapai tingkat yang tinggi. Dengan hasil yang tinggi tersebut maka perbedaan antara para siswa akan berada di tingkat minimum (Sever, 1997:55).

Pendekatan ini dikombinasikan pula dengan pendekatan pembelajaran melalui pengalaman yang menurut Andresen, Boud \& Cohen dalam Fol- 
ley (2000:103), EBL didasarkan pada seperangkat asumsi tentang belajar dari pengalaman. Seperangkat asumsi tersebut yaitu: (1) Pengalaman adalah dasar dan stimulus untuk belajar, (2) Pembelajar aktif membangun pengalaman mereka sendiri, (3) Peserta didik adalah proses holistik, (4) Belajar dikonstruksi secara sosial dan kultural, 5) Belajar dipengaruhi oleh konteks sosioemosional di mana ia terjadi.

Model pelatihan ini menggunakan setting di kelas dan juga setting di tempat bekerja yaitu di rumah keluarga tempat bekerja. Peneliti menggunakan asumsi yang digunakan oleh Boud et al, bahwa pengalaman adalah menjadi dasar dan stimulus untuk belajar artinya pengalaman yang telah dialami oleh baby sitter dalam dunia pekerjaannya menjadi dasar dari apa yang akan mereka pelajari di dalam pelatihan. Pelatihan di kelas, menggunakan teknik refleksi dari apa yang telah mereka alami di dunia pekerjaan untuk dapat digali apa yang perlu diperbaiki dan apa yang harus ditingkatkan.

Pendekatan lain yang digunakan untuk melengkapi pendekatan mastery learning dalam penelitian ini maka digunakan pula pola pendekatan dari pembelajaran berbasis masalah (Problem Based Learning). Gagasan utama dari Problem based Learning (PBL) adalah bahwa titik awal untuk belajar harus dari suatu permasalahan, pertanyaan atau teka-teki yang dengan hal tersebut warga belajar berkeinginan untuk meme- cahkannya (Boud \& Felletti dalam Folley (2000).

Beberapa prinsip yang mendasari pembelajaran berbasis masalah yaitu: (1) masalah diangkat saat pertama dalam urutan belajar, sebelum ada persiapan atau belajar telah terjadi; (2) situasi permasalahan disajikan kepada peserta pelatihan persis seperti yang ada dalam kenyataan; (3) peserta pelatihan bekerja dengan permasalahan yang diangkat, dengan cara yang memungkinkannya meningkatkan kemampuan dengan berbagai alasan dan menantang dengan menerapkan pengetahuan serta mengevaluasi sesuai dengan tingkatan belajar dari warga belajar tersebut; (4) Keterampilan dan pengetahuan yang diperoleh melalui pembelajaran dengan masalah tersebut, diterapkan kembali ke masalah; (5) Pembelajaran yang terjadi dalam penyelesaian masalah dan dalam proses pembelajaran mandiri (individual learning) dirangkum dan diintegrasikan ke dalam pengetahuan dan keterampilan peserta pelatihan yang telah terbentuk.

Model pelatihan in-service berbasis kompetensi ini mengutamakan pada peningkatan kompetensi tenaga kerja baby sitter dalam upaya untuk meningkatkan pelayanan kepada pengguna jasa untuk bidang kepengasuhan anak di rumah.

Adapun secara bagan, model konseptual pelatihan in-service berbasis kompetensi dalam meningkatkan profesionalisme baby sitter tersebut adalah sebagai berikut :

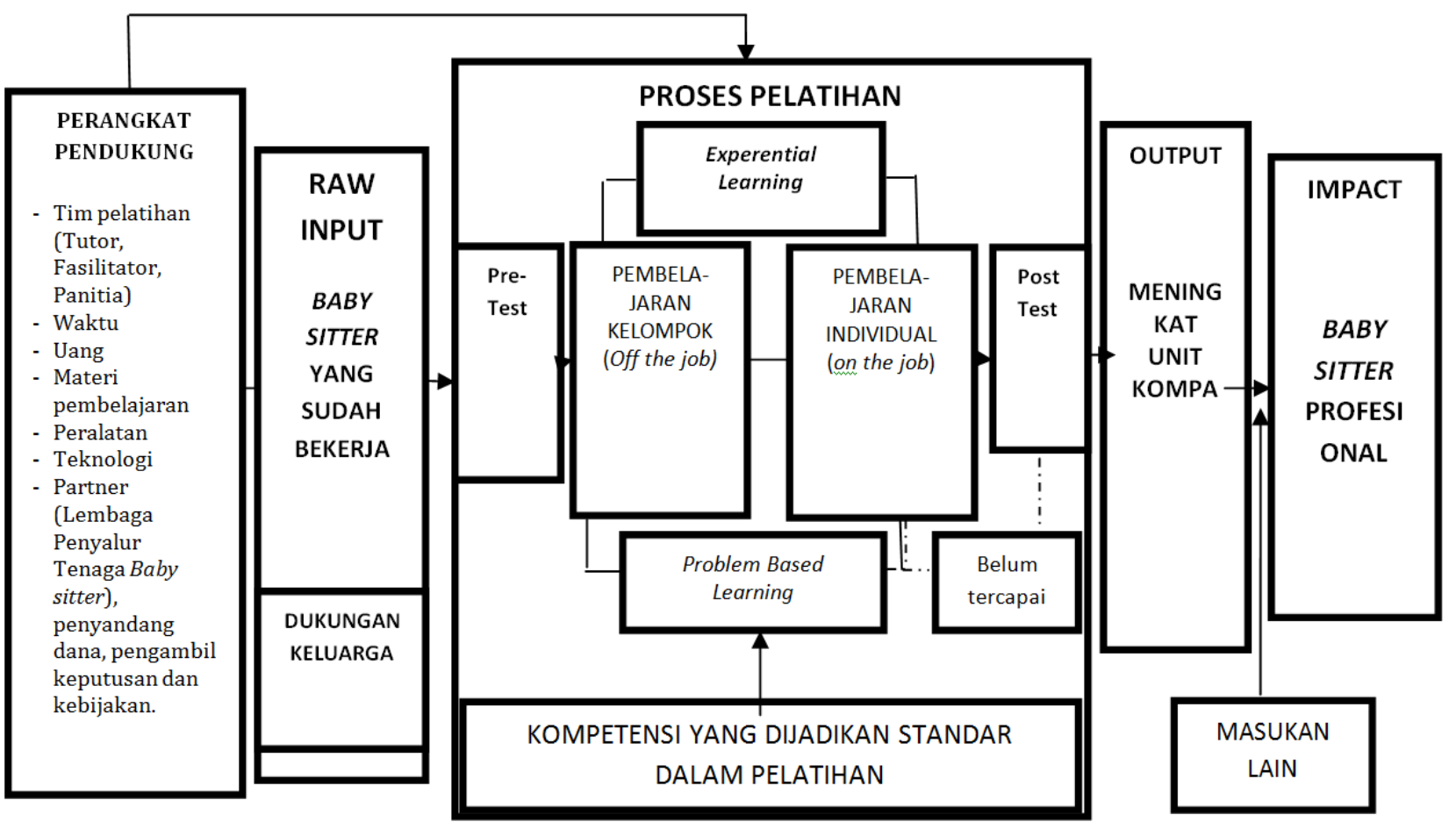

Gambar 1. Bagan Model Konseptual Pelatihan In-service Berbasis Kompetensi dalam Meningkatkan Profesionalisme Baby Sitter

(Model diadaptasi dan dikembangkan dari bagan bagan sistem pelatihan (Sudjana, D : 2000) 
2) Tujuan

Model pelatihan ini memiliki tujuan untuk meningkatkan performance baby sitter di dunia kerja sesuai kompetensi yang menjadi tuntutan pekerjaan sehingga profesionalisme baby sitter dapat tercapai. Keterbatasan penelitian menjadikan fokus utama dalam pengembangan penelitian ini adalah dalam meningkatkan unit kompetensi mendukung perkembangan anak (KOMPA).

3) Sasaran

Kelompok sasaran dari model pelatihan inservice ini adalah baby sitter yang sudah bekerja di keluarga pengguna jasa dan mendapatkan dukungan dari keluarga yang mempekerjakannya.

Untuk model ini, sasaran yang dapat mengikuti pelatihan in-service meliputi kriteria :

a) berusia 18-36 tahun;

b) jenis kelamin perempuan;

c) pendidikan minimal Sekolah Dasar;

d) sudah bekerja sebagai baby sitter, minimal 1 tahun;

e) bersedia mengikuti pelatihan dan mau meningkatkan kompetensi kerja;

f) mendapatkan dukungan dari keluarga untuk mengikuti pelatihan.

4) Prinsip Penerapan

Prinsip penerapan model yang dilakukan adalah:

a) Prinsip pembelajaran mastery learning yang berorientasi pada pencapaian kompetensi, yang artinya pencapaian dalam aspek pengetahuan, keterampilan, sikap dan nilai yang sesuai dengan acuan yang ada

b) Pembelajaran berbasis masalah (PBL/Problem Based Learning), artinya materi diawali dengan memunculkan dan mendiskusikan masalah serta problem solving dari permasalahan yang sudah dialami.

c) Pembelajaran aktif dan menyenangkan, artinya digunakan strategi pelatihan yang efektif dan efisien serta andragogis.

d) Pembelajaran berbasis pengalaman (EBL/ Experential Based Learning) menjadi prinsip pembelajaran. Artinya dengan melaksanakan on the job training menjadikan pelatihan dan pembelajaran dilakukan dengan mengalami langsung apa yang harus dilakukan. Peserta akan mendapatkan fasilitasi dari fasilitator dengan memberikan pengalaman langsung di tempat bekerja

e) Individual learning, artinya dalam pelatihan setting kelas, peserta pelatihan dibekali oleh tutor berbagai pengetahuan dan pemahaman mengenai kompetensi yang harus dimiliki, dan dalam pengembangannya, peserta dibekali dengan tugas-tugas mandiri yang harus dilakukan di lapangan, dengan fasilitasi di tempat bekerja.

5) Pengembangan Standar Kompetensi

Model pelatihan ini adalah berbasis kompetensi, artinya pelatihan yang dilaksanakan mengacu pada pencapaian pada standar kompetensi yang sudah ditetapkan dan ditentukan sesuai dengan bidang kerja dan keterampilan, pengetahuan, sikap dan nilai yang dibutuhkan untuk lingkup pekerjaan tersebut. Standar kompetensi yang digunakan adalah berdasarkan standar kompetensi mix antara standar kompetensi internasional, yaitu certificate III bidang kerja baby sitter, assissten childcare, out of scholl yang digunakan di Australia, SKKNI (Standar Kompetensi Kerja Nasional Indonesia) dan Standar Pendidikan Anak Usia Dini dalam Permendiknas no. 58 tahun 2009. Standar kompetensi mix tersebut terdiri dari 13 unit kompetensi inti yang menjadi ukuran profesionalisme seorang baby sitter.

Keterbatasan peneliti dalam mengembangkan seluruh unit kompetensi, menjadikan model pelatihan in-service pada penelitian fokus pada pengembangan salah satu unit kompetensi yaitu unit kompetensi mendukung perkembangan anak (KOMPA). Model pelatihan in-service berbasis kompetensi bagi baby sitter yang dilaksanakan ini diharapkan dapat meningkat kompetensi baby sitter dalam unit kompetensi mendukung perkembangan anak (unit KOMPA) yang akan mendukung dalam pencapaian profesionalisme baby sitter.

Adapun unit kompetensi mendukung perkembangan anak (KOMPA) meliputi perkembangan: (1) anak dalam kelompok usia yang sesuai, (2) fisik anak sesuai kelompok usia yang sesuai, (3) sosial anak sesuai dengan kelompok usia yang sesuai, (4) emosi dan psikologi anak pada usia yang sama, (5) bahasa anak untuk kelompok usia yang sesuai, (6) kreatif anak sesuai dengan tingkat usia yang sesuai; (7) kognitif sesuai dengan kelompok usia yang sesuai dan (8) spiritual dan keagamaan sesuai dengan kelompok usia yang sesuai. 
Tabel 1. Struktur Kurikulum Unit Kompetensi Mendukung Perkembangan Anak (KOMPA)

\begin{tabular}{|c|c|c|c|c|}
\hline Elemen Kompetensi & Pengetahuan & Keterampilan & Kriteria Unjuk Kerja & $\begin{array}{l}\text { Jumlah } \\
\text { JP }\end{array}$ \\
\hline $\begin{array}{l}\text { 1. Mendukung perkem- } \\
\text { bangan anak dalam } \\
\text { kelompok usia yang } \\
\text { sesuai }\end{array}$ & $\begin{array}{l}\text { Mengetahui pola per- } \\
\text { kembangan anak dan } \\
\text { perbedaan-perbedaan } \\
\text { kemampuan anak pada } \\
\text { tingkat usia yang ber- } \\
\text { beda }\end{array}$ & $\begin{array}{l}\text { Mampu memberikan } \\
\text { fasilitatoran yang tepat } \\
\text { dan membangun sesuai } \\
\text { tingkat perkembangan } \\
\text { anak sehingga anak ter- } \\
\text { bangun kemandiriannya }\end{array}$ & $\begin{array}{l}\text { - Memberikan dorongan pada setiap anak } \\
\text { sesuai tingkatan usianya. } \\
\text { - Menggunakan bahasa dengan tepat dalam } \\
\text { kompleksitas bahasa dan kehangatannya } \\
\text { - Menunjukkan komunikasi yang relevan de- } \\
\text { ngan ketertarikan dan kapabilitas anak } \\
\text { - Menunjukkan harapan pada tingkah laku anak } \\
\text { yang sesuai dengan tingkat perkembangan } \\
\text { anak. } \\
\text { - Menunjukkan strategi dan pengelolaan tingkah } \\
\text { laku pengasuhan yang tepat dengan tingkat } \\
\text { pemahaman anak } \\
\text { - Menunjukkan intensitas fasilitatoran yang } \\
\text { disesuaikan dengan kemampuan dari perkem- } \\
\text { bangan anak. } \\
\text { - Menunjukkan tipe fasilitatoran pada anak } \\
\text { untuk meningkatkan perkembangan akan } \\
\text { kemandirian anak } \\
\text { - Menunjukkan komunikasi yang respek pada } \\
\text { anak, merespon anak dan mengikuti anak }\end{array}$ & $8 \mathrm{JP}$ \\
\hline $\begin{array}{l}\text { a) Mendukung perkem- } \\
\text { bangan fisik anak } \\
\text { sesuai kelompok } \\
\text { usia yang sesuai }\end{array}$ & $\begin{array}{l}\text { Mengetahui pola } \\
\text { perkembangan fisik } \\
\text { anak } \\
\text { Mengetahui cara men- } \\
\text { stimulasi perkembangan } \\
\text { fisik anak yang tepat }\end{array}$ & $\begin{array}{l}\text { mampu menyediakan } \\
\text { pengalaman yang te- } \\
\text { pat melalui kegiatan ru- } \\
\text { tin dalam permainan, } \\
\text { stimulasi alat mainan } \\
\text { dan peralatan lain yang } \\
\text { tepat dalam mendukung } \\
\text { perkembangan fisik anak }\end{array}$ & $\begin{array}{l}\text { - Menunjukkan aktivitas rutin harian yang } \\
\text { dijadikan kesempatan untuk melatih dan } \\
\text { mempraktekkan keterampilan/skill fisik anak } \\
\text { dalam kegiatan rutin sehari-hari } \\
\text { - Menunjukkan aktivitas menggunakan pera- } \\
\text { latan bermain dan mainan untuk membangun } \\
\text { keterampilan/skill fisik anak }\end{array}$ & 8JP \\
\hline $\begin{array}{l}\text { b) Mendukung perkem- } \\
\text { bangan sosial anak } \\
\text { sesuai dengan ke- } \\
\text { lompok usia yang } \\
\text { sesuai. }\end{array}$ & $\begin{array}{l}\text { Mengetahui bagaimana } \\
\text { mendukung anak dalam } \\
\text { membangun persaha- } \\
\text { batan dengan teman } \\
\text { dan mengetahui cara } \\
\text { memberi pemahaman } \\
\text { pada anak akan aturan } \\
\text { di masyarakat/ lingkun- } \\
\text { gan sekitar }\end{array}$ & $\begin{array}{l}\text { mampu mengkondisikan } \\
\text { interaksi anak pada ling- } \\
\text { kup satu teman, interaksi } \\
\text { dengan lingkup kelompok } \\
\text { kecil dan interaksi den- } \\
\text { gan lingkup kelompok } \\
\text { besar }\end{array}$ & $\begin{array}{l}\text { - Mengikuti bersama anak berbagai kegiatan } \\
\text { dan acara-acara yang secara budaya dilaku- } \\
\text { kan di lingkungan masyarakat } \\
\text { - Menyediakan kesempatan untuk interaksi } \\
\text { dengan satu teman, interaksi dengan ke- } \\
\text { lompok kecil dan interaksi dengan kelompok } \\
\text { lebih besar. } \\
\text { - Menunjukkan cara komunikasi yang tepat } \\
\text { sehingga dapat menjadi model yang baik } \\
\text { untuk anak. } \\
\text { - Memberikan pemahaman akan perbedaan, } \\
\text { melalui penilaian dan respek ketika dalam } \\
\text { berbicara mengenai anak dan dengan anak. } \\
\text { - Memberikan kesempatan pada individu anak } \\
\text { dan kelompok anak untuk dapat mengambil } \\
\text { keputusan selama ada pada lingkungan } \\
\text { yang aman }\end{array}$ & 8JP \\
\hline $\begin{array}{l}\text { c) Mendukung perkem- } \\
\text { bangan emosi dan } \\
\text { psikologi anak pada } \\
\text { usia yang sama }\end{array}$ & $\begin{array}{l}\text { Mengetahui tentang } \\
\text { pengembangan konsep } \\
\text { diri, percaya diri, dan } \\
\text { mengatasi emosi anak }\end{array}$ & $\begin{array}{l}\text { mampu menyediakan } \\
\text { kesempatan pada anak } \\
\text { untuk mengambil kepu- } \\
\text { tusan dan menunjukan } \\
\text { perhatian pribadi }\end{array}$ & $\begin{array}{l}\text { - Menunjukkan usaha dan upaya menghargai, } \\
\text { mendukung dan mengapresiasi anak. } \\
\text { - Menunjukkan perhatian penuh pada anak } \\
\text { - Menunjukkan perhatian pada perasaan anak } \\
\text { dengan merespon secara terbuka dan penuh } \\
\text { respek }\end{array}$ & 8JP \\
\hline $\begin{array}{l}\text { d) Mendukung perkem- } \\
\text { bangan bahasa } \\
\text { anak untuk kelom- } \\
\text { pok usia yang ses- } \\
\text { uai }\end{array}$ & $\begin{array}{l}\text { Mengetahui mengenai } \\
\text { pola perkembangan ba- } \\
\text { hasa dapat terbentuk/ } \\
\text { terbangun pada anak }\end{array}$ & $\begin{array}{l}\text { mampu berinteraksi me- } \\
\text { lalui berbahasa yang te- } \\
\text { pat dengan anak dan } \\
\text { menyediakan pengala- } \\
\text { man yang tepat untuk } \\
\text { perkembangan bahasa } \\
\text { anak }\end{array}$ & $\begin{array}{l}\text { - Memberikan dukungan pada anak untuk dapat } \\
\text { mengekspresikan diri secara verbal/lisan } \\
\text { - Memberikan pengalaman-pengalaman agar } \\
\text { anak dapat mengungkapkan berbagai bentuk- } \\
\text { bentuk bahasa. }\end{array}$ & $8 J P$ \\
\hline $\begin{array}{l}\text { e) Mendukung perkem- } \\
\text { bangan kreatif anak } \\
\text { sesuai dengan } \\
\text { tingkat usia yang } \\
\text { sesuai. }\end{array}$ & $\begin{array}{l}\text { Mengetahui pentingnya } \\
\text { kreativitas dan menge- } \\
\text { tahui cara menyediakan } \\
\text { kesempatan pada anak } \\
\text { untuk mengekspresikan } \\
\text { kreativitas }\end{array}$ & $\begin{array}{l}\text { mampu memberikan } \\
\text { fasilitatoran dalam ber- } \\
\text { main dalam imaginasi, } \\
\text { drama, melukis, meng- } \\
\text { gambar, bermain malam } \\
\text { (playdough), menari, } \\
\text { musik, puisi dan menulis }\end{array}$ & $\begin{array}{l}\text { - Memberikan berbagai kesempatan pada anak } \\
\text { untuk menggunakan seluruh rasa mereka } \\
\text { - Memberikan dukungan pada anak-anak untuk } \\
\text { mengekspresikan imajinasi dan kreativitas } \\
\text { dalam interaksi bermain mereka } \\
\text { - Memberikan berbagai pengalaman yang } \\
\text { mendukung anak agar dapat mengeksplorasi }\end{array}$ & 8JP \\
\hline
\end{tabular}




\begin{tabular}{|c|c|c|c|c|}
\hline Elemen Kompetensi & Pengetahuan & Keterampilan & Kriteria Unjuk Kerja & $\begin{array}{l}\text { Jumlah } \\
\text { JP }\end{array}$ \\
\hline & & komposisi lagu. & $\begin{array}{l}\text { dan mengekspresikan diri. } \\
\text { - Menyediakan sumber peralatan dan alat yang } \\
\text { tepat sehingga dapat memudahkan anak } \\
\text { mengembangkan aktivitas kreatif. }\end{array}$ & \\
\hline $\begin{array}{l}\text { f) Mendukung perkem- } \\
\text { bangan kognitif } \\
\text { sesuai dengan ke- } \\
\text { lompok usia yang } \\
\text { sesuai }\end{array}$ & $\begin{array}{l}\text { Mengetahui bagaimana } \\
\text { kognisi dapat terbentuk }\end{array}$ & $\begin{array}{l}\text { Mampu menyediakan } \\
\text { pengalaman dan peng- } \\
\text { kondisian untuk memberi } \\
\text { dukungan lingkungan } \\
\text { untuk stimulasi dalam } \\
\text { perkembangan kognisi } \\
\text { anak }\end{array}$ & $\begin{array}{l}\text { - Memberikan lingkungan dan kesempatan-ke- } \\
\text { sempatan agar dapat memberikan stimulasi } \\
\text { perkembangan kognitif } \\
\text { - Memberikan dukungan agar anak dapat } \\
\text { mengeksplorasi dan menyelesaikan perma- } \\
\text { salahan dengan peralatan dan pengalaman } \\
\text { mereka yang beraneka ragam }\end{array}$ & 8JP \\
\hline $\begin{array}{l}\text { g) Mendukung perkem- } \\
\text { bangan spiritual dan } \\
\text { keagamaan sesuai } \\
\text { dengan kelompok } \\
\text { usia yang sesuai }\end{array}$ & $\begin{array}{l}\text { Mengetahui pentingnya } \\
\text { penanaman spiritual/ } \\
\text { keagamaan pada anak } \\
\text { sejak dini }\end{array}$ & $\begin{array}{l}\text { Mampu menyediakan } \\
\text { pengalaman dan peng- } \\
\text { kondisian untuk memberi } \\
\text { dukungan lingkungan } \\
\text { untuk stimulasi dalam } \\
\text { perkembangan spiritual } \\
\text { dan keagamaan anak }\end{array}$ & $\begin{array}{l}\text { - Mendukung keluarga dalam melaksanakan } \\
\text { ritual keagamaan secara proporsional } \\
\text { - Memperkenalkann anak pada ciptaan Tuhan } \\
\text { - Mendukung anak untuk melakukan kegiatan } \\
\text { berdoa } \\
\text { - Mengarahkan anak untuk melatih melak- } \\
\text { sanakan ritual keagamaan sesuai agamanya }\end{array}$ & 8JP \\
\hline
\end{tabular}

6) Pengelolaan Pembelajaran

\section{a) Perencanaan}

Pengelolaan pembelajaran memiliki langkahlangkah yang dimulai dari perencanaan, pelaksanaan dan evaluasi. Davis dalam Syafraruddin (2005) menjelaskan bahwa perencanaan pembelajaran adalah pekerjaan yang dilakukan oleh seorang tutor untuk merumuskan tujuan pembelajaran

Untuk dapat menghasilkan pembelajaran yang efektif, perencanaan pembelajaran dalam pelatihan, melalui tahapan-tahapan sebagai berikut yaitu: pertama, analisis kebutuhan, dimana pada tahapan ini, melibatkan perbandingan apa yang ada dan apa yang diharapkan dengan menyusun intervensi dalam pelatihan. Kedua, analisis situasi, yang pada tahap-an ini melibatkan penilaian dari peserta pelatihan dan analisis sumber yang tersedia untuk desain dan mengimplementasikan pelatihan. Ketiga, penentuan pekerjaan dan analisis tugas, pada tahapan ini melibatkan mengidentifikasi keterampilan dan pengetahuan yang harus dibangun untuk menunjukan kompetensi dari suatu pekerjaan. Keempat, spesifikasi tujuan dari tingkah laku, dimana menulis standar penampilan yang terukur dan menspesifikasikan kondisi dimana penampilan akan terlihat. Kelima, menyeleksi, mendesain, dan memproduksi materi pelatihan. Pada tahapan ini melibatkan menyeleksi, mendesain dan memproduksi metode dan media yang akan digunakan dalam program pelatihan. Keenam, menyeleksi, mendesain, dan memproduksi materi evaluasi, yaitu meliputi menyeleksi, mendesain dan memproduksi instrumen yang digunakan dalam menentukan tujuan tingkah laku yang sudah dicapai.

Berbagai komponen yang harus dipersiapkan meliputi komponen kelembagaan, sosialisasi program pada keluarga pengguna jasa, pemateri, fasilitator, tempat, sarana prasarana, waktu, biaya, termasuk strategi dan metode pembelajaran dalam pelatihan dan instrumen evaluasi program.

\section{b) Pelaksanaan}

Pelaksanaan pembelajaran dalam model pelatihan ini, membutuhkan kerjasama dan dukungan dari berbagai pihak yang terlihat. Berbagai pihak yang menentukan keberhasilan program ini adalah baby sitter, keluarga pengguna jasa tempat baby sitter bekerja, lembaga penyalur tenaga kerja, kesiapan tutor dan fasilitator, sarana prasarana, serta berbagai hal lain yang ikut mempengaruhi pelaksanaan program.

Pelaksanaan program membutuhkan adanya 3 $\mathrm{K}$ yaitu komunikasi, koordinasi dan kontrol yang baik dari berbagai pihak yang terlibat. Untuk mendukung itu perlu diadakan semacam panduan-panduan yang akan mengkoordinasikan, mengkomunikasikan dan mengontrol pelaksanaan program pelatihan ini. Panduan yang perlu dipersiapkan dalam mengatur pelaksanaan program adalah panduan bagi tutor, panduan bagi fasilitator, skenario pembelajaran dalam pelatihan, dan daftar media pembelajaran yang dibutuhkan dalam pelatihan.

c) Evaluasi

Evaluasi ditujukan untuk menilai pencapaian tujuan yang telah ditetapkan dan menilai proses implementasi pelatihan secara keseluruhan juga menilai kegiatan evaluasi itu sendiri (systemic evaluation approach). Hasil dari evaluasi ini dapat menjadi umpan balik untuk perbaikan dan penyempurnaan program pelatihan yang dilaksanakan, baik dalam pengembangan komponen-komponen kurikulum maupun untuk penentu kebijakan dalam pengambilan keputusan.

Model ini mengembangkan evaluasi berbasiskan pada kompetensi yang sudah dikembangkan untuk menilai keberhasilan pencapaian hasil pembelajaran dalam pelatihan, melalui tes unjuk kinerja maupun tes 
tertulis. Selain dari pada itu, instrumen lain yang digunakan untuk melihat proses pembelajaran, baik melalui penilai peserta pelatihan terhadap tutor dan fasilitator, partisipasi peserta dalam pembelajaran serta penilaian peserta dan tutor terhadap pelaksanaan pelatihan secara umum. Sehingga evaluasi dilakukan pada tiga titik waktu, yaitu: evaluasi sebelum pelatihan, evaluasi pada saat pelatihan dan evaluasi setelah pelatihan dilaksanakan. Keseluruhan evaluasi itu ditujukan untuk menilai pencapaian tujuan yang telah ditetapkan.

7) Struktur Kurikulum

Struktur kurikulum pelatihan berbasis kompetensi, tentunya akan mengacu pada kompetensi atau tujuan yang ingin dicapai. Struktur kurikulum berbasis kompetensi yang dilaksanakan untuk unit kompetensi mendukung perkembangan anak (unit KOMPA) meliputi delapan elemen kompetensi yang terdiri dari pengetahuan, keterampilan, sikap dan nilai-nilai. Berikut adalah elemen kompetensi yang menjadi tujuan dari pelatihan untuk unit KOMPA: (1) mendukung perkembangan anak dalam kelompok usia yang sesuai, (2) mendukung perkembangan fisik anak sesuai kelompok usia yang sesuai, (3) mendukung perkembangan sosial anak sesuai dengan kelompok usia yang sesuai, (4) mendukung perkembangan emosi dan psikologi anak pada usia yang sesuai, (5) mendukung perkembangan bahasa anak untuk kelompok usia yang sesuai; (6) mendukung perkembangan kreatif anak sesuai dengan tingkat usia yang sesuai, (7) mendukung perkembangan kognitif sesuai dengan kelompok usia yang sesuai, dan (8) mendukung perkembangan spiritual dan keagamaan sesuai dengan kelompok usia yang sesuai.

8) Strategi Pembelajaran

Strategi pembelajaran ini berkaitan dengan cara atau sistem penyampaian isi kurikulum dalam usaha dalam pencapaian tujuan yang telah ditetapkan. Keberhasilan dalam pembelajaran banyak ditentukan oleh strategi pembelajaran dalam pelatihan yang dilaksanakan oleh tutor, maupun fasilitator.

Pendekatan pembelajaran yang diterapkan pada model pelatihan in-service berbasis kompetensi ini menyesuaikan dengan prinsip penerapan yang telah diungkapkan sebelumnya bahwa berupa pembelajaran tuntas (mastery learning), pembelajaran aktif dengan pembelajaran berbasiskan masalah dan pembelajaran berbasis pengalaman.

9) Tenaga Tutor dan Fasilitator Pelatihan

Tutor memiliki peran utama dalam memberikan fasilitasi dalam pelatihan di setting kelompok dalam kelas. Kriteria tutor adalah seorang praktisi yang memahami masalah yang berkaitan dengan materi untuk pencapaian unit kompetensi yang dikembangkan.
Sedangkan fasilitator memiliki tugas membantu dan memfasilitasi peserta baby sitter di tempat bekerjanya sendiri, yaitu di keluarga asal tempat baby sitter bekerja.

Tutor adalah tenaga yang menjadi nara sumber dalam pelatihan untuk menyampaikan materi umum mengenai unit kompetensi mendukung perkembangan anak. Kriteria tutor adalah berasal dari tenaga edukatif yang memiliki pemahaman dan pengalaman yang mumpuni di bidang yang sesuai dengan materi dan kompetensi yang akan dibangun. Fasilitator adalah tenaga yang merupakan bagian dari model pelatihan, yang sudah terseleksi, sesuai kriteria dan sebelumnya mendapatkan pelatihan. Fasilitator adalah tenaga yang memiliki kriteria tertentu, khususnya memahami masalah yang berkaitan dengan materi unit KOMPA (Kompetensi Mendukung Perkembangan Anak) dan sudah menjadi praktisi di bidang pekerjaan pendidikan anak usia dini, serta memiliki keterampilan sebagai seorang fasilitator.

10) Metode Pembelajaran

Pendekatan pembelajaran dalam pelatihan yang dilakukan melalui off the job dan on the job training, menjadikan pelatihan dilakukan dengan dua setting tempat. Pembelajaran pada off the job dilakukan melalui metode pembelajaran ceramah, diskusi, kerja kelompok, dan demonstrasi. Pada prinsipnya pelatihan dapat menggali pengalaman dan pembelajaran berbasis masalah.

Pembelajaran selanjutnya dilakukan pembelajaran yang dilakukan secara individual melalui fasilitasi di tempat bekerja yaitu di keluarga (on the job). Pendekatan ini mendasari pelatihan yang untuk sebuah bentuk pembelajaran mastery/ketuntasan.

11) Bahan dan Media Belajar

a) Bahan Belajar

Bahan belajar yang digunakan adalah berbagai sumber belajar yang berkaitan dengan pencapaian kompetensi yang menjadi standar. Standar kompetensi dan kriteria unjuk kerja yang ada menjadi patokan peserta dalam mencari bahan pendalaman materi dari berbagai sumber yang tersedia, maupun sumber yang direferensikan dalam pelatihan.

b) Media Belajar

Media belajar yang digunakan dalam pelatihan dibagi menjadi dua setting pembelajaran, yaitu setting pembelajaran kelompok dan setting pembelajaran individual di tempat kerja. Media pembelajaran di kelas yaitu dengan menggunakan berbagai media yang mendukung terjadinya proses pembelajaran yang aktif dan menyenangkan melalui simulasi serta menggunakan pendekatan pembelajaran berbasis masalah. Berbagai 
media yang digunakan seperti: flip chart, papan tulis, infocus, kartu game, alat simulasi, dsb.

Media pembelajaran yang digunakan di tempat bekerja yaitu dengan menggunakan peralatan yang memungkinkan peserta pelatihan mengkreasikan hasil pengetahuan dan pemahaman di kelas serta arahan dari fasilitator di lapangan tempat bekerja. Tempat bekerja yang digunakan adalah dalam lingkup keluarga tempat baby sitter tersebut bekerja.

c) Evaluasi Pembelajaran

Evaluasi pembelajaran yang dilakukan dalam model ini adalah menggunakan systemic evaluation approach, artinya keefektifan dari model pelatihan in-service berbasis kompetensi dalam meningkatkan profesionalisme baby sitter ini akan dievaluasi secara keseluruhan (Bramley,1996).

Salah satu pengujian yang dilakukan untuk menguji keefektifan pelatihan secara keseluruhan yaitu dengan melakukan pengujian dengan melaksanakan tes, yaitu dengan menyelenggarakan pre-test dan post test sebelum dan sesudah pelatihan, juga observasi dalam lingkup tempat bekerja pada saat sebelum dan sesudah pelatihan melalui format tes unjuk kerja dalam pekerjaan. Tes yang diberikan adalah berupa tes tertulis dan tes unjuk kerja yang akan dilakukan penilaiannya oleh orang penilai yaitu penilai dari luar dan penilai dari keluarga pengguna jasa.

Selain itu penilaian secara proses akan menggunakan instrumen observasi dan wawancara dalam pelaksanaan dan penyampaian materi dari tutor kepada peserta pelatihan dan dari fasilitator terhadap peserta di tempat bekerja, juga hasil forum grup peserta pelatihan mengenai penilaian pada penyelenggaraan pelatihan secara umum Sebagai tambahan data, dilakukan pula penilaian proses terhadap aspek partisipasi peserta pelatihan dalam pembelajaran di dalam setting kelompok maupun individual di tempat bekerja di keluarga.

\section{PENUTUP}

\section{Kesimpulan}

Standar minimal baby sitter yang diharapkan, diantaranya memiliki kebersihan diri, kerapihan, bisa menyesuaikan diri dengan anak dan keluarga, mampu mengurus kebutuhan anak seperti susu, makan dan pakaian anak dengan baik, dan dapat menjadi penghubung antara orang tua dan anak, khususnya mendengarkan kebutuhan anak ketika orang tuanya tidak ada.

Harapan dari baby sitter bahwa mereka membutuhkan materi mengenai cara cepat disukai dan memahami anak, mengajarkan kebiasaan yang baik pada anak, kreatifitas dan inisiatif baby sitter, cara menghadapi kritik dari mitra dan lingkungan, komunikasi dalam memberitahu apabila anak itu salah, dan menu makanan anak sesuai usia

Berdasarkan hasil analisis dan kompilasi, maka standar kompetensi mix dalam model pelatihan ini meliputi standar kompetensi mix yang menjadi standar kompetensi pelatihan ini terdiri dari 13 unit kompetensi. Dari 13 unit kompetensi tersebut, unit KOMPA (Kompetensi mendukung perkembangan anak) adalah unit kompetensi yang sangat penting dan mendasar bagi baby sitter dan merupakan kebutuhan minimal dari pengguna jasa dan menjadi fokus penelitian.

Model ini menentukan standar kompetensi acuan bagi tenaga baby sitter (mix competence) yang disesuaikan dengan kebutuhan pengguna jasa. Acuan ini yang menjadi tujuan pelatihan sekaligus patokan penilaian sehingga harapannya peserta menjadi mastery, melalui pendekatan pelatihan yang berbasis masalah dan melalui pengalaman langsung. Sasaran utama dari model ini adalah baby sitter yang telah bekerja dan mendapatkan dukungan dari keluarga pengguna jasa untuk mengikuti pelatihan.

Setting pelatihan dilakukan melalui baik off the job training maupun utamanya melalui on the job training dengan melaksanakan kegiatan pembelajaran individual langsung di tempat bekerja (keluarga). Fasilitator menjadi sebuah elemen terpenting yang harus dipersiapkan dengan baik agar model pelatihan in-service berbasis kompetensi efektif dalam meningkatkan profesionalisme baby sitter.

\section{DAFTAR PUSTAKA}

Blanchard, P. N., \& Thacker, J. W. (2007). Effective training : systems, strategies, and practices (3rd ed.). Upper Saddle River, N.J: Pearson Prentice Hall.

Bowes, Jennifer M \& Hayes, A. (Ed). (1999). Children,
Families, and communities, contexts and consequences. Oxford University Press

Burke, J. W. (1989). Competency based education and training. London; New York: Falmer Press. Foley, G. (Ed.). (2000). Understanding adult educa- 
tion and training (Second ed.). NSW Australia: Allen \& Unwin.

Gay, L. R., Mills, G. E., \& Airasian, P. W. (2009). Educational research: Competencies for analysis and applications (9th ed.). Upper Saddle River, N.J.: Merrill/Pearson.

George M. Piskurich, P. B., Brandon Hall (Ed.). (2000). The ASTD handbook of training design and delivery. New York: McGraw-Hill.

Haris, R. (1995). Competency-based Education and Training: Between a Rock and a Whirpool. South Melbourne: Macmillan Education Australia.

Idi, A. (2007). Pengembangan kurikulum, teori \& praktik. Ar-Ruzz Media, Jogyakarta

Mulyasa, E. (2002). Kurikulum berbasis kompetensi, konsep, karakteristik dan implementasi. Bandung: Remaja Rosda Karya.

Rycus, P. D. Judith S.e.a. (2000). What is competencybased inservice training? Washington, DC : Institute for Human Services.

Sever, S. (1997). Turkish teaching and mastery learning. Ani Yayincilik: Ankara.
SKKNI (Standar Kompetensi Kerja Nasional Indonesia) Standar kompetensi internasional certificate III (bidang kerja baby sitter, asissten childcare, out of scholl) yang digunakan di Australia,

Standar Pendidikan Anak Usia Dini dalam Permendiknas no. 58 tahun 2009.

Sudjana, D. (2000). Manajemen program pendidikan. Bandung : Falah Production

Sudjana, D. (2004). Pendidikan luar sekolah (Wawasan sejarah perkembangan filsafah dan teori pendukung azaz). Bandung : Nusantara Perss.

Tennant, M. (2006). Psychology and adult learning. USA and Canada: Routledge.

Weatherman, R. (1976). Competency-based inservice training for coordinators of special needs in vocational education. Minnesota University, Washington DC.

Wolf, A. (1995). Competence-based assessment. Buckingham, Philadelphia: Open University Press. 